\title{
Dendritic cell vaccination in pediatric gliomas: lessons learnt and future perspectives
}

\section{Matthias Eyrich*, Johannes Rachor, Susanne C. Schreiber, Matthias Wölfl and Paul G. Schlegel}

Department of Pediatric Oncology, University Children's Hospital, University of Würzburg, Würzburg, Germany

Edited by:

Peter Bader, University Hospital for

Childhood and Adolescence

Medicine, Germany

Reviewed by:

Tobias Feuchtinger, University

Children's Hospital, Germany

Ettore Biagi, University of

Milano-Bicocca, Italy

*Correspondence:

Matthias Eyrich, University Children's

Hospital, Josef-Schneider-Straße 2,

D30 D-97080 Würzburg, Germany

e-mail: eyrich_m@klinik.uni-

wuerzburg.de
Immunotherapy of malignant gliomas with autologous dendritic cells (DCs) in addition to surgery and radiochemotherapy has been a focus of intense research during the past decade. Since both children and adults are affected by this highly aggressive brain tumor, $10-15 \%$ of the several hundred vaccinated patients represent children, making pediatric glioma patients the largest uniform pediatric vaccination cohort so far. In general, DC vaccination in malignant gliomas has been shown to be safe and several studies with a non-vaccinated control group could clearly demonstrate a survival benefit for the vaccinated patients. Interestingly, children and adolescents below 21 years of age seem to benefit even more than adult patients. This review summarizes the findings of the 25 clinical trials published so far and gives a perspective how DC vaccination could be implemented as part of multimodal therapeutic strategies in the near future.

Keywords: pediatrics, malignant glioma, DC vaccination, clinical trial, immunotherapy

\section{INTRODUCTION}

Since the earliest descriptions of dendritic cells (DCs) in skin (1) and later also in lymph nodes (2), their pivotal role in the regulation of immune responses has been recognized. It was primarily in histopathological analyses of easy accessible skin tumors that indicated a close interaction of skin DCs and T helper cells (3). These data led to groundbreaking murine studies showing that DCs pulsed with tumor-extracts can significantly delay cancer growth (4), result in humoral and cellular immune responses (5), and confer in vivo resistance to tumor challenge (6). Quite rapidly, these findings have been translated into clinical studies, one of the first clinical trials in patients with follicular B-cell lymphoma reported no humoral responses but increased cellular proliferation in $4 / 4$ treated patients and clinical responses of various degree in 3/4 (7). Thousands of articles have been published since then (a recent PubMed search with the keywords "DCs and vaccination and tumor" provides 2348 articles), however, results from up-to-date clinical trials still yield no superior results than in the earliest studies. Although this seems daunting at a first glance, many important lessons have been learnt from these trials.

Dendritic cell vaccination has been performed targeting many different tumor entities, the majority of which belonging to types of cancer typically occurring in adults (melanoma, renal cell carcinoma, breast, colon, and prostate cancer). Malignant glioma has also gained considerable attention in the field, and this tumor is a tumor entity relevant also in pediatric oncology. Even with most recent multimodal treatment strategies, the majority of children will relapse within 5 years and die of progressive disease (8). Thus, this review focuses on insights, advances, and translational aspects in the field of DC vaccination studies for malignant gliomas.

\section{CURRENT STATE OF THE ART}

Several murine models using vaccination with DCs in malignant glioma models have shown that this approach holds considerable promise in treating this highly aggressive brain tumor $(9,10)$. Moreover, there is any evidence that vaccination with DC, even when using whole brain lysate as antigen source, may break tolerance to CNS epitopes $(11,12)$. This may be explained by the lifespan of mature DC in peripheral lymphoid organs, which is probably only 1-2 to a maximum of 9 days (13), thereby limiting contact time and potential interactions with naïve $\mathrm{T}$ cells. Mature DCs are not capable of dividing or self-sustaining anymore, and their intrinsically activated apoptotic pathways have been shown to be pivotal for the prevention of autoimmunity $(14,15)$. However, despite the short shelf life of migratory DCs, antigens from injected DCs can be transferred to endogenous DCs from host tissue possibly prolonging and enhancing presentation of tumor antigens. In contrast to migratory DCs, these endogenous, tissue-resident DCs have a significantly extended lifespan (13). This process of antigen transfer has been shown to be important for full activation of $\mathrm{CD}^{+} \mathrm{T}$-cell responses and requires an additional, simultaneous TLR activation stimulus $(16,17)$. Another interesting observation pointed toward the role of oligodendrocytes in preventing CNS-autoimmunity: these intraparenchymal, CNS-resident cells are highly effective in purging the peripheral repertoire of autoreactive $\mathrm{T}$ cells (18). Whether this mechanism also applies to tumor associated CNS-antigens remains to be determined.

After intradermal injection, DCs migrate to the next draining lymph nodes (dLN), where the first cells already appear after 30 min with a maximum of DC influx after $48 \mathrm{~h}(19,20)$. Thereafter, numbers of antigen-loaded DCs sharply decline due to apoptosis and become undetectable with conventional imaging within 6 days. With more sensitive genetic marking techniques traces of migratory DCs $(<1 \%)$ have been detected up to 14 days postinjection (21). Skin-derived DC subsets which repopulate the dLN more continuously $(19,20)$ as well as LN-resident DCs (22) probably enforce and prolong this antigen-presentation beyond the lifespan of injected, migratory DCs. Several studies have analyzed 
the body distribution of DCs after intradermal, subcutaneous, or intravenous injection. In humans, significantly more DCs reach the dLN after intradermal than after subcutaneous injection (2326), so that intradermal application has become the standard delivery route in most trials. However, current estimations from nuclear imaging studies suggest that only $2-4 \%$ of injected DCs succeed to migrate to the dLN (27).

Cytotoxic T lymphocytes (CTLs) which have been successfully activated by a tumor antigen presenting DC have to be imprinted with a specific signature of adhesion molecules in order to be able to traffic to the tumor site in the CNS. For CNS-specific homing, the expression of the integrin VLA-4 (a heterodimer of $\alpha 4$, CD49d and $\beta 1$, CD29) seems to be particularly important (28), although other molecules such as CXCR3 play a role as well (29). The capacity of a DC to induce VLA-4 expression was dependent on the site where the DC picked up the antigen (30) and VLA-4 expression could be inhibited by IL-4 (31). Quite unexpectedly, a recent paper demonstrated that the effectiveness of a DC vaccine was inversely correlated to the proximity of the injection site to the tumor (32). Whether these findings have a clinical relevance and what the specific requirements for an in vitro-matured DC are to induce VLA-4 ${ }^{+}$CTLs in vivo remains to be determined in future investigations.

To the best of our knowledge, based on an extended literature search, so far there are 25 published articles on DC vaccination in human glioma patients (total of 414 patients, among those approximately 50 children) have been published so far (Table $\mathrm{S} 1$ in Supplementary Material). Of these, two were case reports $(33,34)$, the others single-center phase I/II studies, four publications included a control group without DC vaccination (35-38). Most studies focused on feasibility and safety, and indeed there is now convincing evidence that $\mathrm{DC}$ vaccination is safe even in brain tumor patients, since no major (>NCI-CTC grade 2) or dose-limiting toxicity has been reported so far. Initial concerns that the use of brain-derived antigens for vaccination could induce autoimmunity like in melanoma $(39,40)$ could not be confirmed. Several studies analyzed the impact of injected cell dose on outcome (41-45). There seems to be no correlation between the number of injected DCs and the clinical or immunological responses, in one study patients receiving lower dosages of DCs $\left(1 \times 10^{6} \mathrm{DCs} /\right.$ vaccine) even had a better overall survival (OS) than cohorts getting higher numbers of injected cells (44). Cell numbers of $>5 \times 10^{7} \mathrm{DCs} /$ vaccine simply seem to be unfeasible, because such high numbers of mature DCs can only be generated in a limited number of patients (42). A shorter interval especially between the first four vaccines seemed to be beneficial (46), in contrast, the optimal duration of vaccine therapy is completely unclear. Some authors favor a continued vaccination regimen in order to maintain an induced immune response (47), however, no valid data in this respect is available so far. One important consideration associated with prolonged exposure to antigen is the induction of tolerance. Although never observed in high-grade gliomas or DC vaccination trials, at least one clinical phase III study using a genetically modified whole-cell cancer vaccine had to be stopped prematurely due to inferior results in the vaccination group (48). Finally, of particular importance is the notion that in an interim analysis of the Leuven cohort children below
20 years of age $(n=14)$ obviously benefited more from DC vaccination than adults $(n=57)$ (49). However, it is too early to estimate whether this reflects a better immune response of vaccinated children or whether fundamental differences in tumor cell biology between children and adults contribute to this phenomenon. Most encouraging is the fact that DC vaccination compared favorably to standard therapy without DCs in all trials with a defined control group $(35-38,50)$. In four of these trials the mean OS in the vaccinated groups was 23.9 months [15.2 (50), 31 (35), 31.0 (37), and 17.3 months (36)] compared to 10.8 months [8.6 (50), 7 (35), 15 (37), and 12.7 months (36)] in the conventional treatment group without vaccination. The fourth study, the only randomized study so far, shows a 2 -year OS of $7.7 \%$ in the vaccinated group versus $0 \%$ in the non-vaccinated patients $(p<0.05)(38)$. These data also compare favorably with survival rates from standard therapy regimens with an OS of 14.6 months for primary (51) and 8.4 months for relapsed GBMs (52). However, these data must be interpreted with caution, since inclusion criteria were not identical and most studies used a historical control group only. Nevertheless, there is an unequivocal trend toward a favorable effect of DC vaccination on patient survival in all studies paired with a positive risk-benefit-assessment which justifies further pursuit of this approach.

\section{DESIGN OF NEXT-GENERATION DC TRIALS}

As outlined above, for several aspects of DC vaccination there is a growing consensus (admittedly at a low level of evidence since randomized trials are still scarce). For other key issues, phase I/II clinical trials are urgently needed before phase III studies or even commercialization of a stringently produced DC vaccine can be imagined. Among these key issues the central question of the optimal maturation cocktail is not answered yet. Basically, the superiority of a cytokine-based maturation cocktail $\pm \mathrm{PGE}_{2}$ (53) over a $\alpha$-type- 1 polarizing cocktail (IFN $\gamma+$ TLR agonists) (43-45) or vice versa has to be shown. Since cytokine-matured DCs frequently produce no or only low-levels of IL-12, this question could be of major relevance, especially since one recent study has demonstrated a correlation between IL-12 production of DCs and time to progression (43). Furthermore, the optimal antigen source (whole tumor protein or mRNA versus peptides) should be determined. As single peptide vaccines have been shown to result in peptide-deficient escape variants $(54,55)$, multipeptide vaccines have recently been used with considerable success $(45,56)$.

Maybe the most important hindrance of immunotherapeutic approaches is the ability of high-grade glioma cells to secrete inhibitory cytokines such as TGF $\beta$ (57) and to promote accumulation and proliferation of suppressive cell populations like regulatory $T$ cells $\left(T_{\text {reg }}\right)$. Infiltration with $T_{\text {reg }}$ is more common and pronounced in higher-grade tumors and in astrocytic than in oligodendroglial tumors $(58,59)$. Although prognostically not of prime importance, infiltration with $\mathrm{T}_{\text {reg }}$ is associated with glioma progression (58) and has been shown to hinder successful immune responses $(60,61)$. Thus, there seem to be effective mechanisms in the tumor microenvironment which prevent the immune response from translating its potency into clinical efficacy. As a consequence, many attempts have been made to specifically counteract 
these mechanisms. Substances interfering with the TGF $\beta$ signaling pathways are currently tested in early clinical trials, e.g., as inactivating antibodies [fresolimumab (62)] or antisense oligonucleotides [trabedersen (63)]. Likewise, $\mathrm{T}_{\text {reg-depleting strategies }}$ have been developed either as depleting antibodies $(61,64)$ or as metronomic, immunomodulatory chemotherapy $(65,66)$. Since many experimental models have shown that $\mathrm{T}_{\text {reg-depletion mod- }}$ ulates the tumor microenvironment (67) and permits the generation of effective antitumor responses $(60,61)$ these substances are attractive candidates for combination with DC vaccination.

Relapsed or refractory high-grade gliomas are extremely aggressive tumors, so that altering patient selection criteria may significantly improve DC vaccination treatment results. In fact, DC vaccination is already being included into primary glioblastoma treatment $(68,69)$ and one group even proceeded to vaccinate low grade glioma patients in an attempt to prevent anaplastic transformation (NCT01635283). Interestingly, patients relapsing after DC vaccination showed an increased chemosensitivity (70), arguing for an inclusion of DC vaccination into existing chemotherapy regimens.

\section{CONCLUDING REMARKS}

Available data on DC vaccination in patients with malignant glioma allow the conclusion that this therapy is safe and feasible. Efficacy data are still of limited conclusiveness but point toward a prolonged survival in some high-risk patients and a favorable risk-benefit-assessment. Although DC vaccination in its current form is not curative in the vast majority of patients, the combination with other immunomodulatory agents, alternating chemoimmunotherapy regimens, and inclusion in treatment

\section{REFERENCES}

1. Billingham RE. Dendritic cells. $J$ Anat (1948) 82(Pt 1-2):93-109.

2. Steinman RM, Kaplan G, Witmer MD, Cohn ZA. Identification of a novel cell type in peripheral lymphoid organs of mice. V. Purification of spleen dendritic cells, new surface markers, and maintenance in vitro. J Exp Med (1979) 149(1):1-16. doi:10.1084/jem.149.1.1

3. Thomas JA, Janossy G, GrahamBrown RA, Kung PC, Goldstein G. The relationship between $\mathrm{T}$ lymphocyte subsets and Ia-like antigen positive nonlymphoid cells in early stages of cutaneous $\mathrm{T}$ cell lymphoma. J Invest Dermatol (1982) 78(2):169-76. doi:10.1111/15231747.ep12506339

4. Knight SC, Hunt R, Dore $\mathrm{C}$, Medawar PB. Influence of dendritic cells on tumor growth. Proc Natl Acad Sci U S A (1985) 82(13):4495-7. doi:10.1073/pnas.82.13.4495

5. Flamand V, Sornasse T, Thielemans K, Demanet $\mathrm{C}$, Leo $\mathrm{O}$, Urbain J, et al. Vaccination with

schedules for better-risk patients will certainly increase the number of patients who will benefit as long-term survivors from DC vaccination. Since pediatric glioma patients seem to be particularly prone to respond to DC immunotherapy, DC vaccination trials in this patient subgroup must be expedited. Despite the fact that regulatory hurdles have recently hindered the dissemination of this approach considerably, the establishment of dedicated vaccination consortiums like the HGG-Immuno network will allow a broader accessibility to this therapy and facilitate the conduct of randomized multicenter trials.

\section{ACKNOWLEDGMENTS}

We would like to thank the Parent's Initiative Group for Children with Leukemia- and Solid Tumors Würzburg e.V. as well as the Tour of Hope Foundation for their continuous support and an unrestricted research grant. Johannes Rachor and Matthias Eyrich were supported by a grant from the IZKF Würzburg (B-107), Matthias Wölfl and Paul G. Schlegel by a program project grant from BayImmuNet (F2-F5121.7.1.1/13/1/2009). This publication was funded by the German Research Foundation (DFG) and the University of Wuerzburg in the funding program Open Access Publishing.

\section{SUPPLEMENTARY MATERIAL}

The Supplementary Material for this article can be found online at http://www.frontiersin.org/Pediatric_Oncology/10.3389/fped. 2013.00012/abstract

\section{Table S1 | Design and results of clinical trials investigating the safety and efficacy of DC vaccination for the treatment of high-grade gliomas in children and adults.}

9. Van Gool S, Maes W, Ardon H, Verschuere T, Van Cauter S, De Vleeschouwer S. Dendritic cell therapy of high-grade gliomas. Brain Pathol (2009) 19(4):694712 doi:10.1111/j.17503639.2009.00316. $\mathrm{x}$

10. Pellegatta S, Cuppini L, Finocchiaro G. Brain cancer immunoediting: novel examples provided by immunotherapy of malignant gliomas. Expert Rev Anticancer Ther (2011) 11(11):1759-74. doi:10.1586/era.11.102

11. Prins RM, Shu CJ, Radu CG, Vo DD, Khan-Farooqi $\mathrm{H}$, Soto $\mathrm{H}$, et al. Anti-tumor activity and trafficking of self, tumor-specific $\mathrm{T}$ cells against tumors located in the brain. Cancer Immunol Immunother (2008) 57(9):127989. doi:10.1007/s00262-008-04611

8. Wolff JE, Driever PH, Erdlenbruch B, Kortmann RD, Rutkowski $\mathrm{S}$, Pietsch $\mathrm{T}$, et al. Intensive chemotherapy improves survival in pediatric high-grade glioma after gross total resection: results of the HIT-GBM-C protocol. Cancer (2010) 116(3):705-12. doi: $10.1002 /$ cncr. 24730

12. Bridle BW, Li J, Jiang S, Chang R, Lichty BD, Bramson JL, et al. Immunotherapy can reject intracranial tumor cells without damaging the brain despite sharing the target antigen. J Immunol (2010)
184(8):4269-75. doi:10.4049/ jimmunol.0901447

13. Kamath AT, Henri S, Battye F, Tough DF, Shortman K. Developmental kinetics and lifespan of dendritic cells in mouse lymphoid organs. Blood (2002) 100(5):1734-41.

14. Chen $M$, Wang $\mathrm{YH}$, Wang $\mathrm{Y}$, Huang L, Sandoval H, Liu YJ, et al. Dendritic cell apoptosis in the maintenance of immune tolerance. Science (2006) 311(5764):1160-4. doi:10.1126/science.1122545

15. Stranges PB, Watson J, Cooper CJ, Choisy-Rossi CM, Stonebraker AC, Beighton RA, et al. Elimination of antigen-presenting cells and autoreactive $\mathrm{T}$ cells by Fas contributes to prevention of autoimmunity. Immunity (2007) 26(5):629-41. doi:10.1016/ j.immuni.2007.03.016
16. Kleindienst P, Brocker T. Endogenous dendritic cells are required for amplification of $\mathrm{T}$ cell responses induced by dendritic cell vaccines in vivo. J Immunol (2003) 170(6): 2817-23. 
17. Petersen TR, Sika-Paotonu D, Knight DA, Simkins HM, Hermans IF. Exploiting the role of endogenous lymphoid-resident dendritic cells in the priming of NKT cells and CD8+ T cells to dendritic cell-based vaccines. PLoS ONE (2011) 6(3):e17657. doi:10.1371/journal.pone.0017657

18. Na SY, Hermann A, SanchezRuiz M, Storch A, Deckert M, Hünig T. Oligodendrocytes enforce immune tolerance of the uninfected brain by purging the peripheral repertoire of autoreactive CD8+ $\mathrm{T}$ cells. Immunity (2012) 37(1):134-46. doi:10.1016/j.immuni

19. Macatonia SE, Knight SC, Edwards AJ, Griffiths S, Fryer P. Localization of antigen on lymph node dendritic cells after exposure to the contact sensitizer fluorescein isothiocyanate. Functional and morphological studies. J Exp Med (1987) 166(6):1654-67. doi:10.1084/jem.166.6.1654

20. Ruedl C, Koebel P, Bachmann M, Hess M, Karjalainen K. Anatomical origin of dendritic cells determines their life span in peripheral lymph nodes. J Immunol (2000) 165(9):4910-6.

21. Garg S, Oran A, Wajchman J, Sasaki S, Maris CH, Kapp JA, et al. Genetic tagging shows increased frequency and longevity of antigen-presenting, skinderived dendritic cells in vivo. Nat Immunol (2003) 4(9):907-12. doi:10.1038/ni962

22. Allan RS, Waithman J, Bedoui $\mathrm{S}$, Jones CM, Villadangos JA, Zhan Y, et al. Migratory dendritic cells transfer antigen to a lymph node-resident dendritic cell population for efficient CTL priming. Immunity (2006) 25(1):153-62. doi:10.1016/j.immuni.2006.04.017

23. Morse MA, Coleman RE, Akabani G, Niehaus $N$, Coleman D, Lyerly HK. Migration of human dendritic cells after injection in patients with metastatic malignancies. Cancer Res (1999) 59(1):56-8.

24. Blocklet D, Toungouz M, Kiss R, Lambermont M, Velu T, Duriau $\mathrm{D}$, et al. 111In-oxine and $99 \mathrm{mTc}$ HMPAO labelling of antigenloaded dendritic cells: in vivo imaging and influence on motility and actin content. Eur J Nucl Med Mol Imaging (2003) 30(3):440-7. doi:10.1007/s00259-002-1001-4

25. Eggert AA, van der Voort R, Torensma R, Moulin V, Boerman OC, Oyen WJ, et al.
Analysis of dendritic cell trafficking using EGFP-transgenic mice. Immunol Lett (2003) 89(1):17-24. doi:10.1016/S01652478(03)00105-6

26. Trakatelli M, Toungouz M, Blocklet D, Dodoo Y, Gordower L, Laporte $\mathrm{M}$, et al. A new dendritic cell vaccine generated with interleukin-3 and interferon-beta induces CD8+ T cell responses against NA17-A2 tumor peptide in melanoma patients. Cancer Immunol Immunother (2006) 55(4):469-74. doi:10.1007/s00262-005-0056-z

27. de Vries IJ, Lesterhuis WJ, Barentsz JO, Verdijk P, van Krieken JH, Boerman OC, et al. Magnetic resonance tracking of dendritic cells in melanoma patients for monitoring of cellular therapy. Nat Biotechnol (2005) 23(11):140713. doi:10.1038/nbt1154

28. Sasaki K, Zhu X, Vasquez C, Nishimura F, Dusak JE, Huang J, et al. Preferential expression of very late antigen-4 on type $1 \mathrm{CTL}$ cells plays a critical role in trafficking into central nervous system tumors. Cancer Res (2007) 67(13):6451-8. doi:10.1158/00085472.CAN-06-3280

29. Kivisäkk P, Trebst C, Liu Z, Tucky BH, Sørensen TL, Rudick RA, et al. T-cells in the cerebrospinal fluid express a similar repertoire of inflammatory chemokine receptors in the absence or presence of CNS inflammation: implications for CNS trafficking. Clin Exp Immunol (2002) 129(3):510$18 . \quad$ doi:10.1046/j.13652249.2002.01947.x

30. Calzascia T, Masson F, Di Berardino-Besson W, Contassot E, Wilmotte R, Aurrand-Lions $\mathrm{M}$, et al. Homing phenotypes of tumor-specific CD8 $\mathrm{T}$ cells are predetermined at the tumor site by crosspresenting APCs. Immunity (2005) 22(2):175-84. doi:10.1016/j.immuni.2004.12.008

31. Sasaki K, Pardee AD, Qu Y, Zhao X, Ueda R, Kohanbash G, et al. IL-4 suppresses very late antigen-4 expression which is required for therapeutic Th1 T-cell trafficking into tumors. $J$ Immunother (2009) 32(8):793-802. doi:10.1097/CJI.0b013e3181acec1e

32. Ohlfest JR, Andersen BM, Litterman AJ, Xia J, Pennell CA, Swier LE, et al. Vaccine injection site matters: qualitative and quantitative defects in CD8 T cells primed as a function of proximity to the tumor in a murine glioma model.
J Immunol (2013) 190(2):613-20. doi:10.4049/jimmunol.1201557

33. Liau LM, Black KL, Martin NA Sykes SN, Bronstein JM, JoubenSteele L, et al. Treatment of a patient by vaccination with autologous dendritic cells pulsed with allogeneic major histocompatibility complex class I-matched tumor peptides. Case Report. Neurosurg Focus (2000) 9(6):e8. doi:10.3171/foc.2000.9.6.9

34. De Vleeschouwer S, Van Calenbergh F, Demaerel P, Flamen P, Rutkowski S, Kaempgen E, et al. Transient local response and persistent tumor control in a child with recurrent malignant glioma: treatment with combination therapy including dendritic cell therapy. Case report. J Neurosurg (2004) 100(5 Suppl Pediatrics):492-7.

35. Yu JS, Liu G, Ying $H$, Yong $W H$ Black KL, Wheeler CJ. Vaccination with tumor lysate-pulsed dendritic cells elicits antigenspecific, cytotoxic T-cells in patients with malignant glioma. Cancer Res (2004) 64(14):4973-9. doi:10.1158/0008-5472.CAN-033505

36. Chang CN, Huang YC, Yang DM, Kikuta K, Wei KJ, Kubota $\mathrm{T}$, et al. A phase I/II clinical trial investigating the adverse and therapeutic effects of a postoperative autologous dendritic cell tumor vaccine in patients with malignant glioma. J Clin Neurosci (2011) 18(8):1048-54. doi:10.1016/j.jocn.2010.11.034

37. Cho DY, Yang WK, Lee HC, Hsu DM, Lin HL, Lin SZ, et al. Adjuvant immunotherapy with wholecell lysate dendritic cells vaccine for glioblastoma multiforme: a phase II clinical trial. World $\mathrm{Neu}$ rosurg (2012) 77(5-6):736-44. doi:10.1016/j.wneu.2011.08.020

38. Jie X, Hua L, Jiang W, Feng F, Feng G, Hua Z. Clinical application of a dendritic cell vaccine raised against heat-shocked glioblastoma. Cell Biochem Biophys (2012) 62(1):91-9. doi:10.1007/s12013011-9265-6

39. Mackensen A, Herbst B, Chen JL, Köhler G, Noppen C, Herr W, et al. Phase I study in melanoma patients of a vaccine with peptide-pulsed dendritic cells generated in vitro from CD34(+) hematopoietic progenitor cells. Int J Cancer (2000) 86(3):385-92. doi:10.1002/(SICI)10970215(20000501)86:3<385::AIDIJC13>3.3.CO;2-K
40. Banchereau J, Palucka AK, Dhodapkar M, Burkeholder S, Taquet $\mathrm{N}$, Rolland $\mathrm{A}$, et al. Immune and clinical responses in patients with metastatic melanoma to CD34(+) progenitor-derived dendritic cell vaccine. Cancer Res (2001) 61(17):6451-8.

41. Liau LM, Prins RM, Kiertscher SM, Odesa SK, Kremen TJ, Giovannone AJ, et al. Dendritic cell vaccination in glioblastoma patients induces systemic and intracranial T-cell responses modulated by the local central nervous system tumor microenvironment. Clin Cancer Res (2005) 11(15):5515-25. doi:10.1158/1078-0432.CCR-050464

42. Sampson JH, Archer GE, Mitchell DA, Heimberger AB, Herndon JE II, Lally-Goss D, et al. An epidermal growth factor receptor variant III-targeted vaccine is safe and immunogenic in patients with glioblastoma multiforme. Mol Cancer Ther (2009) 8(10):2773-9. doi:10.1158/15357163.MCT-09-0124

43. Okada H, Kalinski P, Ueda R, Hoji A, Kohanbash G, Donegan TE, et al. Induction of CD8+ T-cell responses against novel gliomaassociated antigen peptides and clinical activity by vaccinations with \{alpha\}-type 1 polarized dendritic cells and polyinosinicpolycytidylic acid stabilized by lysine and carboxymethylcellulose in patients with recurrent malignant glioma. J Clin Oncol (2011) 29(3):330-6.

44. Prins RM, Soto H, Konkankit V, Odesa SK, Eskin A, Yong WH, et al. Gene expression profile correlates with T-cell infiltration and relative survival in glioblastoma patients vaccinated with dendritic cell immunotherapy. Clin Cancer Res (2011) 17(6):160315. doi:10.1158/1078-0432.CCR10-2563

45. Akiyama Y, Oshita C, Kume A, Iizuka A, Miyata $\mathrm{H}$, Komiyama $\mathrm{M}$, et al. Alpha-type-1 polarized dendritic cell-based vaccination in recurrent high-grade glioma: a phase I clinical trial. BMC Cancer (2012) 12(1):623. doi:10.1186/1471-2407-12-623

46. De Vleeschouwer S, Fieuws S, Rutkowski S, Van Calenbergh F, Van Loon J, Goffin J, et al. Postoperative adjuvant dendritic cell-based immunotherapy in patients with relapsed glioblastoma multiforme. Clin 
Cancer Res (2008) 14(10):3098104. doi:10.1158/1078-0432.CCR07-4875

47. Suso EM, Dueland S, Rasmussen AM, Vetrhus T, Aamdal S, Kvalheim G, et al. hTERT mRNA dendritic cell vaccination: complete response in a pancreatic cancer patient associated with response against several hTERT epitopes. Cancer Immunol Immunother (2011) 60(6):809-18. doi:10.1007/s00262-011-0991-9

48. Goldman B, DeFrancesco L. The cancer vaccine roller coaster. Nat Biotechnol (2009) 27(2):129-39. doi:10.1038/nbt0209-129

49. Kramm C, Butenhoff S, Rausche U, Warmuth-Metz M, Kortmann R-D, Pietsch T, et al. Pediatric high-grade gliomas. Monatsschr Kinderheilkd (2008) 156:1201-7. doi:10.1007/s00112-008-1799-3

50. Yu JS, Wheeler CJ, Zeltzer PM, Ying H, Finger DN, Lee PK, et al. Vaccination of malignant glioma patients with peptide-pulsed dendritic cells elicits systemic cytotoxicity and intracranial T-cell infiltration. Cancer Res (2001) 61(3):842-7.

51. Stupp R, Mason WP, van den Bent MJ, Weller M, Fisher B, Taphoorn MJ, et al. Radiotherapy plus concomitant and adjuvant temozolomide for glioblastoma. N Engl J Med (2005) 352(10):987-96. doi:10.1056/ NEJMoa043330

52. Wick A, Felsberg J, Steinbach JP, Herrlinger U, Platten M, Blaschke $B$, et al. Efficacy and tolerability of temozolomide in an alternating weekly regimen in patients with recurrent glioma. $J$ Clin Oncol (2007) 25(22):335761. doi:10.1200/JCO.2007.10.7722

53. Jonuleit H, Kühn U, Müller G, Steinbrink K, Paragnik L, Schmitt E, et al. Pro-inflammatory cytokines and prostaglandins induce maturation of potent immunostimulatory dendritic cells under fetal calf serum-free conditions. Eur $J$ Immunol (1997) 27(12):3135-42. doi:10.1002/eji.1830271209

54. Sampson JH, Heimberger AB, Archer GE, Aldape KD, Friedman AH, Friedman HS, et al. Immunologic escape after prolonged progression-free survival with epidermal growth factor receptor variant III peptide vaccination in patients with newly diagnosed glioblastoma. J Clin Oncol (2010) 28(31):4722-9. doi:10.1200/JCO.2010.28.6963

55. Rezvani K, Yong AS, Mielke S, Jafarpour B, Savani BN, Le $\mathrm{RQ}$, et al. Repeated PR1 and WT1 peptide vaccination in Montanide-adjuvant fails to induce sustained high-avidity, epitope-specific CD8+ $\mathrm{T}$ cells in myeloid malignancies. Haematologica (2011) 96(3):432-40. doi:10.3324/haematol.2010.03 1674

56. Phuphanich S, Wheeler CJ, Rudnick JD, Mazer M, Wang $\mathrm{H}$, Nuño MA, et al. Phase I trial of a multi-epitopepulsed dendritic cell vaccine for patients with newly diagnosed glioblastoma. Cancer Immunol Immunother (2012) 62(1):125-35. doi:10.1007/s00262-012-1319-0

57. Siepl C, Bodmer S, Frei K, MacDonald HR, De Martin R, Hofer E, et al. The glioblastomaderived $\mathrm{T}$ cell suppressor factor/transforming growth factorbeta 2 inhibits T cell growth without affecting the interaction of interleukin 2 with its receptor. Eur J Immunol (1988) 18(4):593-600. doi:10.1002/eji.1830180416

58. Grauer OM, Nierkens S, Bennink E, Toonen LW, Boon L, Wesseling $\mathrm{P}$, et al. CD4+FoxP3+ regulatory $\mathrm{T}$ cells gradually accumulate in gliomas during tumor growth and efficiently suppress antiglioma immune responses in vivo. Int J Cancer (2007) 121(1):95-105. doi:10.1002/ijc.22607

59. Heimberger AB, Abou-Ghazal M, Reina-Ortiz C, Yang DS, Sun W, Qiao W, et al. Incidence and prognostic impact of FoxP3+ regulatory $\mathrm{T}$ cells in human gliomas. Clin Cancer Res (2008) 14(16):516672. doi:10.1158/1078-0432.CCR08-0320

60. Grauer OM, Sutmuller RP, van Maren W, Jacobs JF, Bennink E, Toonen LW, et al. Elimination of regulatory $\mathrm{T}$ cells is essential for an effective vaccination with tumor lysate-pulsed dendritic cells in a murine glioma model. Int $J$ Cancer (2008) 122(8):1794-1802. doi:10.1002/ijc.23284
61. Morse MA, Hobeika AC, Osada T, Serra D, Niedzwiecki D, Lyerly HK, et al. Depletion of human regulatory $\mathrm{T}$ cells specifically enhances antigen-specific immune responses to cancer vaccines. Blood (2008) 112(3):610-18 doi:10.1182/blood-2008-01135319

62. Trachtman H, Fervenza FC Gipson DS, Heering P, Jayne DR, Peters $\mathrm{H}$, et al. A phase 1 , single-dose study of fresolimumab, an anti-TGF-beta antibody, in treatment-resistant primary focal segmental glomerulosclerosis. Kidney Int (2011) 79(11):1236-43. doi:10.1038/ki.2011.33

63. Bogdahn U, Hau P, Stockhammer G, Venkataramana NK, Mahapatra AK, Suri A, et al. Targeted therapy for high-grade glioma with the TGF-beta2 inhibitor trabedersen: results of a randomized and controlled phase IIb study. Neuro-oncology (2011) 13(1):13242. doi:10.1093/neuonc/noq142

64. Dannull J, Su Z, Rizzieri D, Yang BK, Coleman D, Yancey D, et al. Enhancement of vaccinemediated antitumor immunity in cancer patients after depletion of regulatory $\mathrm{T}$ cells. $J$ Clin Invest (2005) 115(12):3623-33. doi:10.1172/JCI25947

65. Ghiringhelli F, Menard C, Puig PE, Ladoire S, Roux S, Martin F, et al. Metronomic cyclophosphamide regimen selectively depletes $\mathrm{CD} 4+\mathrm{CD} 25+$ regulatory $\mathrm{T}$ cells and restores $\mathrm{T}$ and NK effector functions in end stage cancer patients. Cancer Immunol Immunother (2007) 56(5):641-8. doi:10.1007/s00262-006-0225-8

66. Banissi C, Ghiringhelli F, Chen L, Carpentier AF. Treg depletion with a low-dose metronomic temozolomide regimen in a rat gliom model. Cancer Immunol Immunother (2009) 58(10):1627-34 doi:10.1007/s00262-009-0671-1

67. Maes W, Rosas GG, Verbinnen B, Boon L, De Vleeschouwer S, Ceuppens JL, et al. DC vaccination with anti-CD25 treatment leads to long-term immunity against experimental glioma. Neuro-oncology (2009) 11(5):529-42. doi:10.1215/ 15228517-2009-004
68. Ardon H, Van Gool S, Lopes IS, Maes W, Sciot R, Wilms $\mathrm{G}$, et al. Integration of autologous dendritic cell-based immunotherapy in the primary treatment for patients with newly diagnosed glioblastoma multiforme: a pilot study. $J$ Neurooncol (2010) 99(2):261-72. doi:10.1007/s11060-010-0131-y

69. Ardon H, Van Gool SW, Verschuere T, Maes W, Fieuws S, Sciot $\mathrm{R}$, et al. Integration of autologous dendritic cell-based immunotherapy in the standard of care treatment for patients with newly diagnosed glioblastoma: results of the HGG-2006 phase I/II trial. Cancer Immunol Immunother (2012) 61(11): 2033-44. doi:10.1007/s00262012-1261-1

70. Wheeler CJ, Black KL, Liu G, Mazer M, Zhang XX, Pepkowitz S, et al. Vaccination elicits correlated immune and clinical responses in glioblastoma multiforme patients. Cancer Res (2008) 68(14):595564. doi:10.1158/0008-5472.CAN07-5973

Conflict of Interest Statement: The authors declare that the research was conducted in the absence of any commercial or financial relationships that could be construed as a potential conflict of interest.

Received: 31 January 2013; paper pending published: 11 March 2013; accepted: 27 May 2013; published online: 10 June 2013.

Citation: Eyrich M, Rachor J, Schreiber SC, Wölfl M and Schlegel PG (2013) Dendritic cell vaccination in pediatric gliomas: lessons learnt and future perspectives. Front. Pediatr. 1:12. doi: 10.3389/fped.2013.00012

This article was submitted to Frontiers in Pediatric Oncology, a specialty of Frontiers in Pediatrics.

Copyright (C) 2013 Eyrich, Rachor, Schreiber, Wölfl and Schlegel. This is an open-access article distributed under the terms of the Creative Commons Attribution License, which permits use, distribution and reproduction in other forums, provided the original authors and source are credited and subject to any copyright notices concerning any third-party graphics etc. 